\title{
A new insect pest in Salix biomass plantations
}

\section{Linnéa Lövgren and Inger Åhman}

Resistance Breeding Department, Svalöf AB, S-268 00 Svalöv, Sweden

A species, new to Sweden, of gall-midge (Cecidomyiidae, Rabdophaga nov.sp.) was found in 1988 in biomass plantations of Salix viminalis L. Whilst feeding, the larvae kill the tip of the shoots resulting in cessation of terminal growth and subsequent side-shoot development. This kind of damage is considered to be severe, especially in nurseries producing cuttings.

The objects of the present project are to investigate the importance of the gall midge as a pest in energy forests and to provide basic biological knowledge and assist in developing methods preventing further damage, by quantification of crop damage, both in terms of reduced production of cuttings in nurseries and effects on biomass production in energy forests, and studies in the life cycle, host range and population dynamics of the gall-midge.

Very little is known about the mechanisms of plant resistance, although significant differences in attack rate between $S$. viminalis-clones occur in the field. Effects of the individual clones on the performance of the gall-midge and its natural enemies have been identified for further examination.

\section{The regeneration of willow scrub in the British uplands}

\section{A. MacDonald}

Nature Conservancy Council for Scotland, 2/5 Anderson Place, Edinburgh, EH6 5NP, U.K.

Scrub and woodland is much reduced in the British uplands compared with Scandinavia, both in the montane and sub-montane zones. High grazing and browsing pressures over many centuries are likely to have been responsible. Reduced stocking levels, at least locally, seem possible in the near future. Regeneration would contribute to the conservation of rare species e.g. montane willows, and would indirectly benefit even some open ground fauna, e.g. black grouse and merlin, by providing shelter, reduced disturbance and alternative sources of food. There is scope also to integrate scrub regeneration with the management of recreational pressure.

Montane, shrubby willows ( $S$. lapponum L., $S$. lanata L., $S$. arbuscula L., $S$. myrsinites L., S. reticulata L.) are of particular concern. Populations are fragmented into very small, often isolated, sometimes single-sex stands. The probability of successful seedling establishment appears to be very low even when grazing is absent. Meanwhile there is a slow but continuous loss of established plants e.g. by rock falls. In the sub-montane zone there is considerable scope for the localised development of willow scrub, particularly of $S$. aurita L. but also of $S$. caprea L., $S$. cinerea L., S. phyllicifolia L. and $S$. nigricans $\mathrm{Sm}$., where grazing pressure is reduced or removed. 